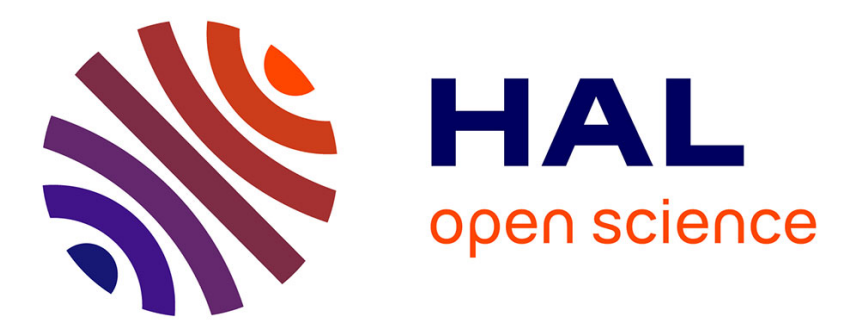

\title{
MOF-Supported Selective Ethylene Dimerization Single-Site Catalysts through One-Pot Postsynthetic Modification
}

\author{
J. Canivet, S. Aguado, Y. Schuurman, D. Farrusseng
}

\section{- To cite this version:}

J. Canivet, S. Aguado, Y. Schuurman, D. Farrusseng. MOF-Supported Selective Ethylene Dimerization Single-Site Catalysts through One-Pot Postsynthetic Modification. Journal of the American Chemical Society, 2013, 135 (11), pp.4195-4198. 10.1021/ja312120x . hal-00826367

\section{HAL Id: hal-00826367 https://hal.science/hal-00826367}

Submitted on 31 Aug 2020

HAL is a multi-disciplinary open access archive for the deposit and dissemination of scientific research documents, whether they are published or not. The documents may come from teaching and research institutions in France or abroad, or from public or private research centers.
L'archive ouverte pluridisciplinaire HAL, est destinée au dépôt et à la diffusion de documents scientifiques de niveau recherche, publiés ou non, émanant des établissements d'enseignement et de recherche français ou étrangers, des laboratoires publics ou privés. 


\title{
MOF-Supported Selective Ethylene Dimerization Single-Site Catalysts through One-Pot Post-Synthetic Modification
}

\author{
Jerome Canivet,* Sonia Aguado, Yves Schuurman and David Farrusseng \\ Institut de Recherches sur la Catalyse et l'Environnement de Lyon (IRCELYON) Université Lyon 1-CNRS 2, Av. Albert \\ Einstein F-69626 Villeurbanne.
}

\begin{abstract}
The one-pot post-functionalization allows anchoring a molecular nickel complex into a mesoporous metal-organic framework (Ni@(Fe)MIL-101). It is generating a very active and reusable catalyst for the liquid-phase ethylene dimerization to selectively form 1-butene. Higher selectivity for 1-butene is found using the Ni@(Fe)MIL-101 catalyst than reported for molecular nickel diimino complexes.
\end{abstract}

The understanding of mechanisms involved in heterogeneously catalyzed reactions is a challenge continuously addressed for several decades. One of the main approaches consists of the "heterogenization" of molecular catalysts, or in other words, the insertion of a metallo complex into or onto a solid by different methods, also known as surface organometallic chemistry. ${ }^{1}$ The role of the support is analogous to that of a rigid ligand in the corresponding molecular complex. However, the grafting of molecular catalysts on the surface of solid oxides has often led to a loss of activity due to detrimental interactions with the support or to mutual deactivation between too close sites. ${ }^{2}$ Generally, the design of isolated single active sites at the support surface is thus essential. ${ }^{3}$ This is specially the case for the development of heterogeneous catalyst for olefin polymerization which remains a challenge because of a drastic loss of the activity upon grafting on support. ${ }^{4}$

In this study we show that Metal-Organic Frameworks constitute an appealing new and relevant platform for the seeding of supported single site catatlysts. ${ }^{5}$ They offer the key advantages of a high site density combined with well-defined and isolated sites for the anchoring of catalytic species. Compared to amorphous silica which has non-homogeneously scattered $\mathrm{OH}$ groups and an average site density from two to six per square nanometer, ${ }^{6}$ the crystalline MOF (Cr) MIL-101 exhibits three to four chromium atoms per square nanometer, equivalent to the density of the organic ligand, homogeneously distributed in a well-ordered framework. ${ }^{7}$ This represents an efficient compromise between high site density and site isolation.

The post-synthetic modification, comprehensively reviewed by Cohen and coworkers, ${ }^{8}$ is a powerful tool for obtaining highly sophisticated functionalized structures. It consists of the introduction of functionalities after framework synthesis and allows the preparation of MOF-supported organometallics following various methods. ${ }^{9}$ However the post-synthetically introduced coordinating moieties could interact with metal nodes, as demonstrated by Banerjee et al. on the (Cr) MIL- $101 .^{10}$ In addition, the use of metal salts as precursors could also lead to pore blocking with metal aggregates ${ }^{11}$ which may also contribute to unselective catalytic activity. ${ }^{12}$

We report here the first one-pot post-synthetic grafting of a nickel-based organometallic catalyst within a MOF framework under mild conditions, preventing the interactions of the organic graft with the metal nodes and the encapsulation of metal particles (Scheme 1). This method allows the rapid preparation of a MOFbased catalyst whose activity and selectivity are demonstrated for the selective ethylene dimerization to give the corresponding alpha olefin (1-butene) in liquid phase.

The (Fe)MIL-101-NH2, which is isostructural to the (Cr)MIL101 7a,13 and is formed by trimeric iron (III) octahedral clusters linked by 2-aminoterephthalate ligands, is selected as starting platform. ${ }^{14}$ Related to its giant-pore MOF parent, the (Fe)MIL$101-\mathrm{NH}_{2}$ can be considered as an ideal candidate thanks to its high pore volume which is able to accommodate organometallic species as well as substrates and to amino groups on its walls acting as a starting platform for post-synthetic functionalization. According to data reported on MIL-101 structure, the amino site density can be evaluated to four per square nanometer. ${ }^{7}$

Scheme 1. One-pot synthesis of the MOF-anchored nickel complex Ni@(Fe)MIL-101 ${ }^{a}$

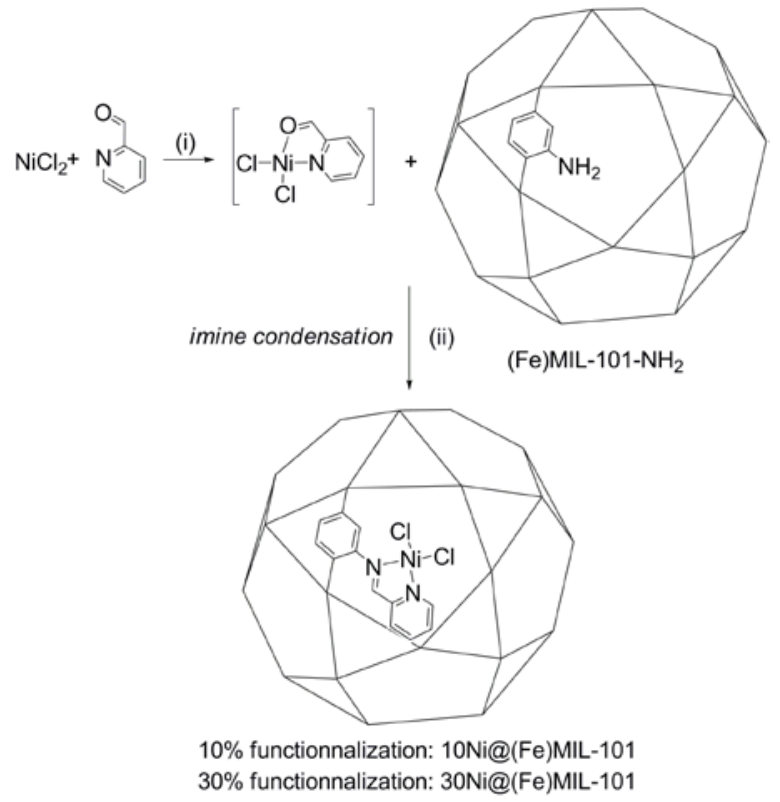

${ }^{a}$ Conditions: (i) $\mathrm{NiCl}_{2}$ and $\mathrm{PyCHO}$ in $\mathrm{MeOH}$; (ii) (Fe)MIL-101$\mathrm{NH}_{2}$ ( $\sim 0.3$ to 1 eq. $-\mathrm{NH}_{2}$ ) stirred at room temperature. 
With the perspective to anchor organometallics into MOF cavities, we aim to create $N, N$-chelating centers from 2aminoterephthalate $\left(\mathrm{BDC}-\mathrm{NH}_{2}\right)$ by the reaction with 2-pyridine carboxaldehyde (PyCHO) to give the corresponding pyridine methanimino group (BDC-NCHPy) onto the MOF walls. In order to avoid the competitive $\mathrm{N}$-coordination of the pyridyl moieties to the coordinatively unsaturated metal sites of the (Fe)MIL-101$\mathrm{NH}_{2},{ }^{7 \mathrm{c}, 14 \mathrm{a}}$ we firstly $\mathrm{N}$-coordinated the pyridyl to the desired nickel salt to allow the formyl group of the compound formed to react with the amino at the MOF walls (Scheme 1).

The imine condensation occurs in the presence of the $\mathrm{Ni}(\mathrm{PyCHO}) \mathrm{Cl}_{2}$ methanolic solution to directly form the diimino nickel complex anchored into the MOF (Scheme 1). Indeed we can expect that the coordination of the nickel to the formyl group could increase its electrophilicity and thus could favor its condensation to the weak nucleophilic amino groups at the MOF walls. The post-modification yield is measured from ${ }^{1} \mathrm{H}$ NMR spectra after sample digestion in $\mathrm{DCl} / \mathrm{D}_{2} \mathrm{O} / \mathrm{dmso}$-d6 (Supporting Information). The condensation proceeds with $10 \%$ yield when one equivalent of $\mathrm{PyCHO} / \mathrm{NiCl}_{2}$ per $-\mathrm{NH}_{2}$ moiety on the $\mathrm{MOF}$ are used and the suspension stirred for 24 hours at room temperature, to give 10Ni@(Fe)MIL-101. Following the same methodology, 30Ni@(Fe)MIL-101, in which 30\% of the amino groups are converted, is obtained using three equivalents of $\mathrm{PyCHO} / \mathrm{NiCl}_{2}$ for 72 hours. The appearance in the NMR spectra of new typical aromatic signals at $8.1,8.6$ and $8.8 \mathrm{ppm}$, corresponding to pyridyl and imine $\mathrm{CH}$ protons, indicates the efficient functionalization of the $\mathrm{BDC}$ aromatic ring.

Unfortunately, the paramagnetic effect of iron (III) leads to a low resolution and a peak broadening in NMR spectra. Nevertheless by using a very low concentration of the MOF in the deuterated solution and consequently a high number of scans, workable spectra are obtained.

PXRD analysis confirms the structural integrity of the materials after the functionalization step (Supporting Information). Additionally, the EDX analyses show the atomic ratios $\mathrm{Ni}: \mathrm{Cl}$ to be $1: 2$ which confirm that all the nickel remains in its dichloride form. Combining NMR and EDX data, we can formulate the desolvated functionalized solids as $\mathrm{Fe}_{3} \mathrm{OCl}\left(\mathrm{BDC}-\mathrm{NH}_{2}\right)_{2.7}$ [(BDCNCHPy)NiCl $]_{0.3}$ for 10Ni@(Fe)MIL-101 and FesOCl(BDC$\left.\mathrm{NH}_{2}\right)_{2}$ [(BDC-NCHPy) $\mathrm{NiCl}_{2}$ ] for 30Ni@(Fe)MIL-101 (Supporting Information).

As expected and according to the $\mathrm{N}_{2}$ adsorption isotherms, the post-modification is accompanied by a decrease of the BET surface, from $1884 \mathrm{~m}^{2} \cdot \mathrm{g}^{-1}$ for (Fe)MIL-101-NH 2 to $1110 \mathrm{~m}^{2} \cdot \mathrm{g}^{-1}$ for 10Ni@(Fe)MIL-101 and $155 \mathrm{~m}^{2} \cdot \mathrm{g}^{-1}$ for 30Ni@(Fe)MIL-101 (Supporting Information). The very low value reported for $30 \mathrm{Ni@(Fe)MIL-101} \mathrm{is} \mathrm{due} \mathrm{to} \mathrm{the} \mathrm{presence} \mathrm{of} \mathrm{a} \mathrm{high} \mathrm{number} \mathrm{of}$ nickel species inside the MOF pores. Indeed the actual complex loading onto the solid is approximately 10 and 33 nickel complexes per MOF cage for 10Ni@(Fe)MIL-101 and 30Ni@(Fe)MIL-101 respectively.7

The continuous increase in the commercial demands for $\mathrm{C}_{4}$ to $\mathrm{C}_{8}$ linear $\alpha$-olefins, which are promising co-monomers of linear low-density polyethylenes, presses forward the development of efficient catalysts for ethylene oligomerization. Major commercial processes, such as SHOP from Shell or Alfabutol from IFP-New Energy, are based on homogeneous catalysts. ${ }^{15}$ Moreover the development of heterogeneous catalysts for olefin polymerization, especially alpha isomers, remains a challenge because the grafting of molecular complexes on support usually leads to a drastic loss of activity compared to that of the homogeneous equivalent. ${ }^{4}$

Having this MOF-supported nickel complexes in hand, we explore their potential as heterogeneous catalysts for this reaction in the liquid phase. Typically, Ni@(Fe)MIL-101 suspended in heptane is allowed to react in the presence of $\mathrm{Et}_{2} \mathrm{AlCl}$ under 15 bars of ethylene. After quenching, the products are analyzed by gas chromatography to determine the catalytic activity defined as moles of oligomers formed per mole of nickel per hour. Results obtained with our solids as well as with analogous molecular species under these "early" conditions are summarized in the Table 1.

As expected, the reaction does not proceed in the presence of the (Fe)MIL-101- $\mathrm{NH}_{2}$ alone or combined with either $\mathrm{NiCl}_{2}$ or PyCHO (entries 1 and 5 to 7). Even if bis(triphenylphosphine)nickel dichloride complex shows the highest activity (entry 2), the Ni@(Fe)MIL-101 catalyst remains more than 10 times more active than its molecular analogue $\mathrm{Ni}$ (bipy) $\mathrm{Cl}_{2}$ (entries 3 and 4). With turnover frequencies up to $3215 \mathrm{~h}^{-1}$ at $10^{\circ} \mathrm{C}$, the catalytic activity found with Ni-functionalized (Fe)MIL-101 is higher than those found for coordination polymer catalysts reported by Angelescu ${ }^{16}$ and Miyake ${ }^{17}$ in the literature (Table S2).

Moreover, the similar activity obtained using $10 \mathrm{Ni}-$ and 30Ni@(Fe)MIL-101 tends to demonstrate that all the catalytic sites are accessible (entries 8 and 9).

It is noteworthy that here almost only 1-butene is formed during the reaction (>95\%, Supporting Information). Using nickel pyridinimino complex anchored into (Fe)MIL-101, higher 1-butene selectivity is found than those commonly reported with molecular bis- or tridentate imino nickel species $(\leq 80 \%),{ }^{18}$ the data remaining however difficult to compare due to differences in reaction conditions.

Table 1. Ni-catalyzed ethylene oligomerization in liquid phase under "early" conditions ${ }^{a}$

\begin{tabular}{|c|c|c|c|c|c|}
\hline \multirow{2}{*}{ Entry } & \multirow{2}{*}{$\begin{array}{l}\text { Catalyst } \\
(\mu \mathrm{mol})^{b}\end{array}$} & \multirow{2}{*}{$\begin{array}{l}\text { Intrinsic } \\
\text { Activity } \\
\left(\mathrm{h}^{-1}\right)^{c}\end{array}$} & \multicolumn{3}{|c|}{ Selectivity $(\%)^{c}$} \\
\hline & & & $\mathrm{C}_{4}$ & $\mathrm{C}_{6}$ & $\mathrm{C}_{8}$ \\
\hline 1 & none & 0 & 0 & 0 & 0 \\
\hline 2 & $\begin{array}{l}\mathrm{Ni}\left(\mathrm{PPh}_{3}\right)_{2} \mathrm{Cl}_{2} \\
(35)\end{array}$ & 9540 & 84 & 15.6 & 0.4 \\
\hline 3 & $\begin{array}{l}\mathrm{Ni}(\text { bipy}) \mathrm{Cl}_{2} \\
\text { (35) }\end{array}$ & 175 & 92 & 8 & 0 \\
\hline 4 & $\begin{array}{l}\mathrm{Ni}(\text { bipy}) \mathrm{Cl}_{2} \\
(2.8)\end{array}$ & 210 & 92 & 7.5 & 0.5 \\
\hline 5 & $(\mathrm{Fe}) \mathrm{MIL}-101-\mathrm{NH}_{2}{ }^{d}$ & 0 & 0 & 0 & 0 \\
\hline 6 & $\begin{array}{l}(\mathrm{Fe}) \mathrm{MIL}-101-\mathrm{NH}_{2} \\
+\mathrm{NiCl}_{2} e\end{array}$ & 0 & 0 & 0 & 0 \\
\hline 7 & $\begin{array}{l}(\mathrm{Fe}) \mathrm{MIL}-101-\mathrm{NH}_{2} \\
+\mathrm{PyCHO} f\end{array}$ & 0 & 0 & 0 & 0 \\
\hline 8 & $\begin{array}{l}\text { 30Ni@(Fe)MIL-101 } \\
(8.4)\end{array}$ & 3215 & 94 & 5.5 & 0.5 \\
\hline 9 & $\begin{array}{l}\text { 10Ni@(Fe)MIL-101 } \\
(2.8)\end{array}$ & 3166 & 95 & 4.5 & 0.5 \\
\hline
\end{tabular}

${ }^{a}$ Reaction performed in of $n$-heptane in the presence of $\mathrm{Et}_{2} \mathrm{AlCl}$ $(\mathrm{Al} / \mathrm{Ni}=70)$ under 15 bars of ethylene at $10^{\circ} \mathrm{C}$; ${ }^{b}$ Based on the amount of Ni, corresponding to 8 mg of Ni@(Fe)MIL-101; ' $E s t i-$ mated by GC analysis and calculated as moles of oligomer formed/(moles of $\mathrm{Ni} \cdot \mathrm{h})$; ${ }^{d}$ Reaction performed using $8 \mathrm{mg}$ of MOF; ${ }^{e}$ Reaction performed using $8 \mathrm{mg}$ of $\mathrm{MOF}$ and $\mathrm{NiCl}_{2}$ (35 $\mu \mathrm{mol}, 4.5 \mathrm{mg}$ ); fReaction performed using $8 \mathrm{mg}$ of MOF and PyCHO $(10 \mu \mathrm{mol}, 1 \mu \mathrm{L})$, the activity is here calculated as moles of oligomer formed $/($ moles of PyCHO $\cdot h)$.

The temperature-dependence of the catalytic activity of 10Ni@(Fe)MIL-101 is highlighted in the Figure 1. The catalytic activity reaches a maximum which is displaced to higher temperatures when the pressure increases. At 30 bars and $25^{\circ} \mathrm{C}$, the high- 
est activity is 10455 moles of oligomers formed per mole of nickel per hour, which corresponds to 205 grams of butene per gram of MOF material per hour. A similar temperature-dependence can be found in literature in the case of homogeneous ${ }^{18 b, 18 d}$ as well as covalently supported nickel diimine molecular catalysts. ${ }^{19}$ Moreover the activity obtained using 10Ni@(Fe)MIL-101 catalyst under optimized conditions is in the range of those reported for supported nickel complexes coordinated either by phosphines ${ }^{20}$ or by sophisticated Schiff bases (Table S2). ${ }^{19,21}$

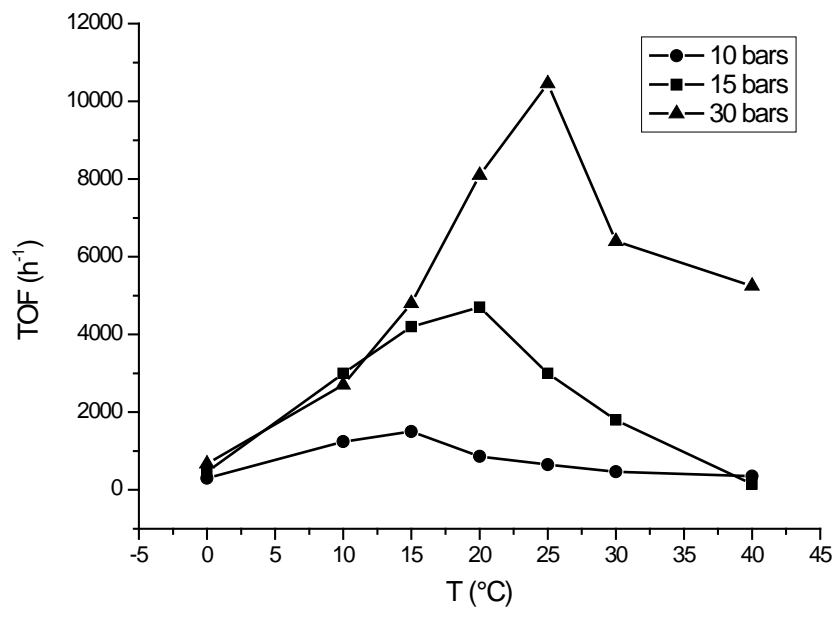

Figure 1. Temperature-dependent activity of 10Ni@(Fe)MIL-101 in the liquid phase ethylene oligomerization.

Leaching test shows that the reaction does not proceed any longer if the filtrated catalytic solution is again put under catalytic conditions in the presence of Al-based co-catalyst. PXRD analysis of 10Ni@(Fe)MIL-101 after a catalytic run confirms that its crystallinity is preserved. Furthermore, the 10Ni@(Fe)MIL-101 can be reused, after careful washings with anhydrous ethanol and drying, for at least two more catalytic runs without significant loss of activity or selectivity (Supporting Information).

In conclusion, we have developed a novel one-pot postfunctionalization of a metal organic framework enabling the immobilization of an active organometallic catalyst in its cavities. This new MOF catalyst is very efficient in the triphasic ethylene dimerization producing selectively 1-butene. The single-site isolation combined with high site density onto the MOF leads to high activity. Furthermore higher selectivity for 1-butene is found using the Ni@(Fe)MIL-101 catalyst than reported for molecular nickel diimino complexes. Thus, this original catalytic porous material, made from relatively cheap precursors, opens new perspectives for the use of MOF-based catalysts in valorization processes.

\section{ASSOCIATED CONTENT}

\section{Supporting Information}

Full synthetic details, compounds characterizations (PXRD, SEM-EDX, NMR, adsorption isotherms) and catalysis. This material is available free of charge via the Internet.

\section{AUTHOR INFORMATION}

\section{Corresponding Author}

jerome.canivet@ircelyon.univ-lyon1.fr

\section{ACKNOWLEDGMENT}

The authors are very grateful to IRCELYON scientific services. This paper reports work undertaken in the context of the project "OCMOL, Oxidative Coupling of Methane followed by Oligomerization to Liquids". OCMOL is a Large Scale Collaborative Project supported by the European Commission in the 7th Framework Programme (GA n²28953). For further information about OCMOL see: http://www.ocmol.eu or http://www.ocmol.com.

\section{REFERENCES}

(1) (a) Candy, J. P.; Didillon, B.; Smith, E. L.; Shay, T. B.; Basset, J. M. J. Mol. Catal. 1994, 86, 179. (b) Coperet, C.; Chabanas, M.; Saint-Arroman, R. P.; Basset, J. M. Angew. Chem.-Int. Ed. 2003, 42, 156. (c) Vidal, V.; Theolier, A.; ThivolleCazat, J.; Basset, J. M. Science 1997, 276, 99.

(2) (a) Corriu, R. J. P.; Mehdi, A.; Reye, C.; Thieuleux, C.; Frenkel, A.; Gibaud, A. New J. Chem. 2004, 28, 156. (b) Joubert, J.; Delbecq, F.; Sautet, P.; Le Roux, E.; Taoufik, M.; Thieuleux, C.; Blanc, F.; Coperet, C.; Thivolle-Cazat, J.; Basset, J.-M. J. Am. Chem. Soc. 2006, 128, 9157.

(3) (a) Pugin, B. J. Mol. Catal. A-Chem. 1996, 107, 273. (b) Zhang, T.; Song, F.; Lin, W. Chem. Commun. 2012, 48, 8766.

(4) (a) Collins, S.; Kelly, W. M.; Holden, D. A. Macromolecules 1992, 25, 1780. (b) Kristen, M. O. Top. Catal. 1999, 7, 89.

(5) (a) Lee, J.; Farha, O. K.; Roberts, J.; Scheidt, K. A.; Nguyen, S. T.; Hupp, J. T. Chem. Soc. Rev. 2009, 38, 1450. (b) Xamena, F.; Abad, A.; Corma, A.; Garcia, H. J. Catal. 2007, 250, 294. (c) Farrusseng, D.; Aguado, S.; Pinel, C. Angew. Chem.-Int. Edit. 2009, 48, 7502. (d) Corma, A.; Garcia, H.; Xamena, F. X. L. Chem. Rev. 2010, 110, 4606.

(6) (a) Vansant, E. F.; Van der Voort, P.; Vrancken, K. C. In Characterization and Chemical Modification of the Silica Surface 1995; Vol. 93, p 149. (b) Zhuravlev, L. T. Langmuir 1987, 3, 316. (c) Coasne, B.; Galarneau, A.; Di Renzo, F.; Pellenq, R. J. M. Langmuir 2006, 22, 11097.

(7) (a) Ferey, G.; Mellot-Draznieks, C.; Serre, C.; Millange, F.; Dutour, J.; Surble, S.; Margiolaki, I. Science 2005, 309, 2040. (b) Wang, B.; Cote, A. P.; Furukawa, H.; O'Keeffe, M.; Yaghi, O. M. Nature 2008, 453, 207. (c) Hong, D.-Y.; Hwang, Y. K.; Serre, C.; Ferey, G.; Chang, J.-S. Adv. Funct. Mater. 2009, 19, 1537.

(8) (a) Cohen, S. M. Chem. Sci. 2010, 1, 32. (b) Wang, Z. Q.; Cohen, S. M. Chem. Soc. Rev. 2009, 38, 1315. (c) Cohen, S. M. Chem. Rev. 2012, 112, 970.

(9) (a) Bhattacharjee, S.; Yang, D.-A.; Ahn, W.-S. Chem. Commun. 2011, 47, 3637. (b) Bloch, E. D.; Britt, D.; Lee, C.; Doonan, C. J.; Uribe-Romo, F. J.; Furukawa, H.; Long, J. R.; Yaghi, O. M. J. Am. Chem. Soc. 2010, 132, 14382. (c) Chavan, S.; Vitillo, J. G.; Uddin, M. J.; Bonino, F.; Lamberti, C.; Groppo, E.; Lillerud, K.-P.; Bordiga, S. Chem. Mater. 2010, 22, 4602. (d) Doonan, C. J.; Morris, W.; Furukawa, H.; Yaghi, O. M. J. Am. Chem. Soc. 2009, 131, 9492. (e) Ingleson, M. J.; Barrio, J. P.; Guilbaud, J. B.; Khimyak, Y. Z.; Rosseinsky, M. J. Chem. Commun. 2008, 2680. (f) Kaye, S. S.; Long, J. R. J. Am. Chem. Soc. 2008, 130, 806. (g) Ma, L.; Falkowski, J. M.; Abney, C.; Lin, W. Nature Chem. 2010, 2, 838. (h) Tanabe, K. K.; Cohen, S. M. Angew. Chem.-Int. Ed. 2009, 48, 7424. (i) Wang, C.; Xie, Z.; deKrafft, K. E.; Lin, W. J. Am. Chem. Soc. 2011, 133, 13445. (j) Zhang, X.; Llabres, F.; Corma, A. J. Catal. 2009, 265, 155.

(10) Banerjee, M.; Das, S.; Yoon, M.; Choi, H. J.; Hyun, M. H.; Park, S. M.; Seo, G.; Kim, K. J. Am. Chem. Soc. 2009, 131, 7524.

(11) Hwang, Y. K.; Hong, D.-Y.; Chang, J.-S.; Jhung, S. H.; Seo, Y.-K.; Kim, J.; Vimont, A.; Daturi, M.; Serre, C.; Ferey, G. Angew. Chem.-Int. Ed. 2008, 47, 4144.

(12) (a) Esken, D.; Zhang, X.; Lebedev, O. I.; Schroder, F.; Fischer, R. A. J. Mater. Chem. 2009, 19, 1314. (b) Meilikhov, M.; Yusenko, K.; Esken, D.; Turner, S.; Van Tendeloo, G.; Fischer, 
R. A. Eur. J. Inorg. Chem. 2010, 3701. (c) Huang, Y. B.; Lin, Z. J.; Cao, R. Chem. Eur. J. 2011, 17, 12706. (d) Muller, M.; Turner, S.; Lebedev, O. I.; Wang, Y. M.; van Tendeloo, G.; Fischer, R. A. Eur. J. Inorg. Chem. 2011, 1876.

(13) Latroche, M.; Surble, S.; Serre, C.; Mellot-Draznieks, C.; Llewellyn, P. L.; Lee, J.-H.; Chang, J.-S.; Jhung, S. H.; Ferey, G. Angew. Chem.-Int. Ed. 2006, 45, 8227.

(14) (a) Bauer, S.; Serre, C.; Devic, T.; Horcajada, P.; Marrot, J.; Ferey, G.; Stock, N. Inorg. Chem. 2008, 47, 7568. (b) Hartmann, M.; Fischer, M. Microporous Mesoporous Mater. 2012, 164, 38.

(15) (a) AlSherehy, F. A. Stud. Surf. Sci. Catal., 1996; Vol. 100. (b) Cauvin, S.; Braunschweig, B.; Galtier, P.; Glaize, Y. Rev. I. Fr. Petrol 1992, 47, 375. (c) Freitas, E. R.; Gum, C. R. Chem. Eng. Prog. 1979, 75, 73. (d) Keim, W. Chem. Ing. Tech. 1984, 56, 850. (e) Keim, W.; Schulz, R. P. J. Mol. Catal. 1994, 92, 21. (f) Lutz, E. F. J. Chem. Educ. 1986, 63, 202. (g) Peuckert, M.; Keim, W. Organometallics 1983, 2, 594. (h) Skupinska, J. Chem. Rev. 1991, 91, 613.

(16) Angelescu, E.; Che, M.; Andruh, M.; Zavoianu, R.; Costentin, G.; Mirica, C.; Pavel, O. D. J. Mol. Catal. A-Chem. 2004, 219, 13.

(17) Kyogoku, K.; Yamada, C.; Suzuki, Y.; Nishiyama, S.; Fukumoto, K.; Yamamoto, H.; Indo, S.; Sano, M.; Miyake, T. J. Jpn. Petrol. Inst. 2010, 53, 308.

(18) (a) de Souza, R. F.; Bernardo-Gusmao, K.; Cunha, G. A.; Loup, C.; Leca, F.; Reau, R. J. Catal. 2004, 226, 235. (b) Liu, F.S.; Gao, H.-Y.; Song, K.-M.; Zhang, L.; Zhu, F.-M.; Wu, Q. Polyhedron 2009, 28, 1386. (c) Smetanyuk, V. I.; Ivanyuk, A. V.; Martynova, M. A.; Komarova, O. P. Petroleum Chemistry 2003, 43, 28. (d) Wang, K.; Gao, R.; Hao, X.; Sun, W.-H. Catal. Commun. 2009, 10, 1730. (e) Lecocq, V.; Olivier-Bourbigou, H. Oil Gas Sci. Technol. 2007, 62, 761.

(19) (a) AlObaidi, F.; Ye, Z. B.; Zhu, S. P. Macromol. Chem. Phys. 2003, 204, 1653. (b) Li, Y.-G.; Pan, L.; Zheng, Z.-J.; Li, Y.-S. J. Mol. Catal. A-Chem. 2008, 287, 57. (c) Schrekker, H. S.; Kotov, V.; Preishuber-Pflugl, P.; White, P.; Brookhart, M. Macromolecules 2006, 39, 6341. (d) Preishuber-Pflugl, P.; Brookhart, M. Macromolecules 2002, 35, 6074.

(20) Braca, G.; Galletti, A. M. R.; Digirolamo, M.; Sbrana, G.; Silla, R.; Ferrarini, P. J. Mol. Catal. A-Chem. 1995, 96, 203.

(21) (a) Song, K.-M.; Gao, H.-Y.; Liu, F.-S.; Pan, J.; Guo, L.H.; Zai, S.-B.; Wu, Q. Catal. Lett. 2009, 131, 566. (b) Choi, Y.; Soares, J. B. P. Macromol. Chem. Phys. 2009, 210, 1979. 


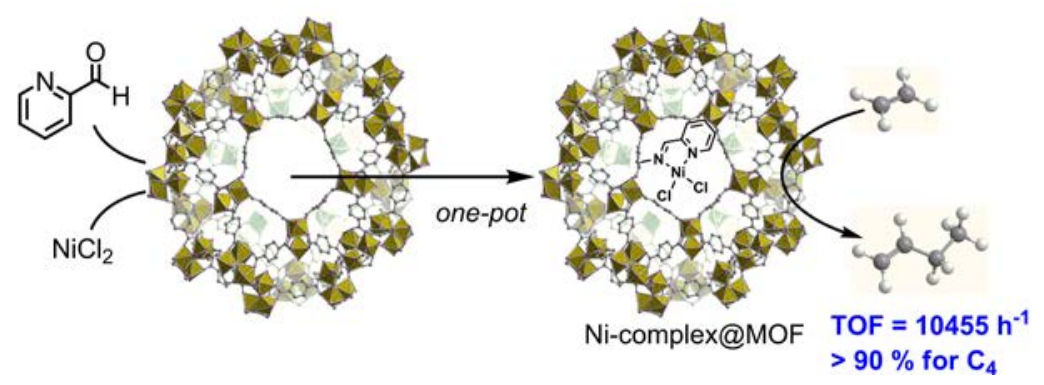

